\title{
Political Discourse: Genre and Figurative Language in the Discourse Debate of the Central Java Governor's Candidate 2018
}

\author{
Dwi Bambang Putut Setiyadi, Universitas Widya Dharma \\ Ana Setyandari, Universitas Widya Dharma
}

\begin{abstract}
The research aims at describing the genre and the figurative language chosen in the discourse debate of the governors' candidate of the Central Java 2018. Descriptive qualitative is used in the research. While, the object of the research is the used of the genre and figurative language by the candidates of the governors between Ganjar Pranowo and Sudirman Said which is presented in the Kompas TV aired on March 8, 2018 and Metro TV aired on March 15, 2018and documented in YouTube program. The technique of collecting the data is gaining from the audiovisual technique by using seven steps of providing data: observation, textualization, multicoloumn, segmentation, thematization, proposionalization, and reduction. The data analysis discourse is also applying in this research by using five main steps, namely: analysed, interpreted, summarized, concluded, and recomended. The result of the study: (1) The genre used in the debate of Governor candidate in Central Java 2018 is macro genre of conversation genre including discussion. The macro genre consists of micro genres covering the description, exposition (argumentation and hortatory), explanations, recount, and procedures. The social function of each genre corresponds to its genre. (2) The aspect of figurative language are found in the form of repetitive use of figurative language, rhetorical, personification, metonymy, metaphor, and hyperbole.
\end{abstract}

Keywords: figurative language; genre; political discourse; the discourse debate

\section{Introduction}

In the Educational and Culture National Discussion (Rembuk Nasional Pendidikan dan Kebudayaan) of 2017, President Jokowi reminded that next year (2018) is the political year (www.cnnindonesia.com). In addition, he said so because in August and September there are already president and vice president election. The presidential and vice presidential candidates must be there for the 2019 presidential election. In the same years (2018), there will be joint elections throughout Indonesia, both provincial and district or city leaders. According to the KPU, there are 171 regions that will conduct provincial and district or city leaders election (read: Pilkada) consisting of 17 provinces, 39 cities, and 115 districts (https://news.detik.com). The elections were held to directly elect the regional head. In the election there are several candidates that each region is different in number of candidates. In Central Java Province was followed by two candidate pairs, namely Ganjar Pranowo paired with Taj Yasin and Sudirman Said paired with Ida Fauziyah. Based on those important activities concerning to the Indonesian political agenda it is appropriate if the year 2018 is called the political year.

Prior to the regional election (Pilkada), the registration of candidates of the regional heads must be done on the condition that has been determined. After the candidates meet the requirements and are designated as candidates for regional heads, they then conduct a number of campaigns, including candidate debates broadcast by private television stations. In this debate, the candidates of regional heads propose leading programs in winning the votes of their constituents. In Indonesia, the debate between candidates with one another on television poses its vision and mission as well as leading programs in public. The participants of the debate are the candidate pair of regional head. They are directed by guides and television presenters to answer the questions of the participants as well as one way to attract potential voters who see the debate. 
The debate was arranged by the hosts of the television show. There are some questions that have been prepared by presenter or experts. In addition, it is also limited by time in the debate as well as the delivery of the program. The candidates must make good and best statements in order to attract the attention of the electorate and ultimately choose the couple. In order for the delivery to be interesting, they choose the most interesting types of texts or styles of language and can convince potential voters to elect them as regional leaders. In addition, in the debate candidates are also trying to convince potential voters in the most attractive fashion possible.

Due to the event of political debates of the regional election (Pilkada) will be held in every province in Indonesia, the researchers are interested in analyzing the debate discourse. In this paper focused on debate the Central Java Governor candidate of the year 2018 on program of "Rosi and Candidate Leaders of Central Java" in Kompas TV and "Candidate Talk" with the topic "Who Deserve Lead Central Java" which was broadcast by Metro TV. Therefore, the problem in this research is formulated as follows.

(1) How did the genre and social function in the debate of Governor candidate in Central Java 2018 in the program of "Rosi and Candidate Leaders of Central Java" in Kompas TV and "Candidate Talk" in the topic of "Who Deserve Lead Central Java"which was broadcast by Metro TV?

(2) What kind of figurative language is selected in the debate?

\section{Discourse, genre, and figurative language}

The term discourse is often interchangeable with text. In this discussion both terms are equated (Setiyadi, 2012; Wulan, 2017). Text is a language unit that can be prepared either written or orally organized according to a particular text structure that expresses contextually meaning. In multimodal, text can be tangible oral or written text and image / animation/ film (Wiratno, 2014). Based on its content there are various discourses or texts, there are political discourse, educational discourse, cultural discourse, discourse of sport, and so forth. Dijk describes studies of political discourse is about the text and talk of professional politicians or political institutions, such as president and prime ministers and other members of government, both at the local, national, and international levels (http://discourses.org/OldArticles).The purpose of political discourse is the conquest and deductions of power; and its participants are politicians and society (Kenzhekanova, 2015).

Another type of discourse or text is the genre (Wiratno, 2014; Ren, 2010). Genre is a term derived from French and it comes from the Latin genus (Bawarshi, 2010). Fairclough describes the relationship between discourse, genres, and styles (Savtoiu \& Popescu, 2014). A discourse is a way of representing some aspect of the world, characterized by specific vocabulary and grammatical features. Genres are a way of communicating and interacting, ways of working, governing or conducting politics. Genre analysis usually uses non-linguistics criteria as a basis for identification and classification (Lieungnapar et.al., 2017).

Wiratno (2014) says that the genre is narrowly defined as the type of text, whereas the broad genre is a gradually oriented social process for the goal. Genre can be classified into some part, there are micro genre and macro genre. In fact, we often find the use of the genre is a mix of micro genre. The function of macro genre becomes a superordinate from themicros genre. The micro genre as the type of text is divided into two groups, namely the factual and fictional genres or the custom genre. Factual genres are subdivided into report types, descriptions, procedures, recount, explanations, expositions, and discussions. The custom genre includes recount, anecdote, narrative, and exemplum.

People used language to express themselves; they used defferent language style to communicate such as using figurative language (Krisnawati, 2017). Figurative language is a language which uses figures of speech (Tambunan \& Sinambela, 2018). Furthermore, another opinion, Mahmood et.al. (2014) said that figurative language is the type of language that uses words or phrases different from the literal meaning. In addition, Hariyanto (2017) also argues that figuratif language is kind of language that the speakers say less than what he means. 
Figurative language has some specific features which make it different from nonfigurative language (Fadaee, 2011).

There are three types of figurative language, namely comparison (simile, metaphor, and personification), opposition (hyperbole, understatement, and irony), links (metonymy, synecdoche, allusion, and eufemism) (Djajasudarma, 2013; Suhardi, 2015). Other experts classify the figurative language into five, namely comparison, repetition, satire, contradiction, and affirmation (Murtafi, et.al., 2017). A language or simply a word contains many hidden meaning behind it. Each word are sometimes very defferent from what we can understand literally (Daniswara et. al., 2016)

\section{Method}

Descriptive qualitative is used in the research. While, the object of the research is the uses of the political discourse by the candidates of the governors between Ganjar Pranowo and Sudirman Said which is presented in the Kompas TV in the program of "Rosi and Candidate Leaders of Central Java" in Kompas TV aired on March 8, 2018 and "Candidate Talk" with the topic of "Who deserve Lead Central Java"which was broadcast by Metro TV aired on March 15, 2018 and documented in YouTube.

Data collection techniques by applying observation techniques and documents from audiovisual materials (Creswell, 2014) is using in this research. The data collection steps use seven steps in providing the data (Sudaryanto, 2016). Observation technique was conducted to observe the debate document of Central Java Governor Candidate in You Tube. The document technique in question is a political discourse document in the Central Java Governor candidate debate that has been recorded in You Tube media in the form of audiovisual. Some steps used in this data collection is to make observations on the debate event conducted by the governors couple by examining at the contents of the discourse. After determining the choice of political discourse that has been shaped the tape and then textualization namely changing the discourse of the conversation of the recordings into durative text. After that, the text that is still single column is being multicolumn in order to know the history of conversation and context of the conversation, both in the form of verbal and nonverbal communication which is also segmented. Furthermore, the durative segments are embedded and proposionalized by the researchers which is produces the statements about the identity of the data, and also the data that is less in accordance with the theme of research is reduced.

Data analysis techniques in this study is using the discourse analysis techniques through some steps of the main data analysis, namely the main data that have been determined analyzed by the interpretation of researchers to determine what genre of discourse, social function, and figurativelanguage used in political discourse in the candidate's debate. If all those have been analyzed and interpreted, then the results are summarized for conclusion and recommended when it was necessary.

\section{Result and Discussion 4.1 Result}

The result of the analysis in this study are the genre discourse which is presented in political discourse of governor candidate debate of the Central Java in the form of mixed genre between macro genre and micro genre. Macro genre is the genre which is contains of several genres of conversation in the form of discussion. Debate includes a genre of discussion that occurs between several people. The debate between the candidates occurred on two televisions, namely Kompas $T V$ and Metro TV. In Kompas TV, candidate pair of Central Java Governor Ganjar Pranowo with his partner Taj Yasin and Sudirman Said paired with Ida Fauziah and presenter Rosi Silalahi, while in Metro TV, presenter Silvi Iskandar plus more with 4 panelists. The function of this genre is to refuse the statement of one candidate pair of the governor with another partner. If there is no approval of the other partner's statement, then one of them will contradict them. 
At the beginning of the debate, it was raised about the background of the two candidates presented by host of both television to introduce each candidates with descriptive discourse genre. The social function of this discourse is to inform viewers about the track record of both candidates. In addition to the host, candidates also use descriptive discourse to describe their programs, such as Farmers Cards, Cement Mill, Poverty Eradication, Culture, etc.

Another genre is reconstruction is also used when the candidates retell their experiences before becoming candidates. In using this discourse, the candidates tell how their joys when Sudirman Said get difficulty in paying tuition fee while he study and helped his counselor teacher. Ganjar Pranowo tells he wandering when looking for a job in Jakarta who was forced to eat noodles and owe to eat. In addition, Taj Yassin also tells the beginning of his life as a tempe craftsman. While, Ida Fauziyah said that there are so many dabbling when she lives in the pesantren. In the debate, there are often raised the statement of Ganjar Pranowo and Sudirman Said in the form of humor discourse so as to invite the laughter of the audience. The function of humor in the conversation discourse conveyed by both partners to attract the attention of viewers.

In the debate there is also the use of discourse genres of candidates who seek to convince the viewers (candidates to vote) to give arguments from the programs presented either its superiority or its weakness. The advantages of candidates according to Ganjar Pranowo who have been well denied by Sudirman Said candidates who then point out the weaknesses of his opponent's program. When given the opportunity, Ganjar Pranowo candidate also denied that it was not true. In this debate both, use genre of analytical exposition and hortatory exposition because to expose and prove the existence of the reasons they forwarding between them. In addition, it is also used explanation genre to state the cause of it done. For example: about the Farmers' Card program, why Sudirman Said wants to replace, poverty eradication program, the provision of 5 million jobs, and women's empowerment program. According to Ganjar Pranowo farming card is a good program, while Sudirman Said says it's a lot of weakness because the card is actually complicating the community. Ganjar Pranowo denied that. Also other programs denied, but the intangible debate of tension, the debate took place seriously but relaxed.

Another genre of discourse is the genre of procedure. This genre exists when the Sudirman Said complains about the procedure of using the Farmer Card which makes it difficult for the community. The genre explains the simple procedure of Sudirman Said programmed that did not bother the public. There is an easy procedure why the procedures that make it difficult for the community. Similarly, in the provision of jobs that will be provided. The text of the procedure is also used by Ganjar Pranowo when explaining about the establishment of Cement Factory Kendeng.

In conveying their ideas (in the debates of Candidate Leaders of Central Java) there are several genre of language found such as repetition as a style of affirmation. It is found in the use of the following candidate languages, for example: (1) Kalau melayani sebagai sebuah impian masyarakat dan bisa kita genapi dengan cara-cara, dengan teknologi, dengan bahasanbahasan yang baik, dengan respon yang baik maka padasaat itu publik akan mendapatkan kepuasannya (Kompas TV), (2) Kita akan punya generasi milenial luar biasa melalui ekonomi kreatif melalu pariwisata melalui industri usaha kecil menengah (Kompas TV); (3) Kita di dunia pesantren itu diajarkan...kita menjaga kebersihan....kita dipesantren itu diajarkan....kita harus menjaga lingkungan...(Metro TV). The repetition of words dengan data (1), the repetition of words melalui (2), and the repetition of words kita (3) is a form of repetition in the speech in an attempt to confirm what the speaker means.

Also found the style of rhetorical language in the form of sentence questions that do not require an answer. The rhetorical figurative language is found in the Ganjar Pranowo statement when it says, for instance: (4) Barangkali jalan-jalan sama saya ya? (Kompas TV); (5) Jadi pilkada terbuka terbuka harus ada kontestasi kan? (Kompas TV); (6) Sapa kuwi? (Metro TV); (7) Bagaimana APBD prosantri dilaksanakan?(Metro TV). Data (4), (5), (6), and (7) are rhetorical questions because they do not require answers. 
Personification is used to attach human nature to inanimate objects or abstract ideas. In the above debate text found, for example in the data (8) Proses harus berjalan (Kompas TV); (9) Jateng bershalawat itu..." (Metro TV). In the data (8) the word berjalan is the personification of the dead object process. Data (9) contains a form of personification of the word shalawat.

The metonymy style is used to proper name or the name of the thing linked to the item, state, or name in its place. For instance this figurative language is found in sentence (10) Jakarta ingin menyelesaikan (Kompas TV); (11) Soal Kendeng ...(Metro TV); (12) Suhu politik yang agak rumit.. The word Jakarta on the data (10) replaces the designation of the existing governmentin Jakarta, Kendeng (11) is a metonymy of the Cement Plant. Data (12) suhu politik is a reference to current political conditions.

The metaphors in the debate are used to cloning shal-things that are abstract or the opposite. For example the form is contained in speech (13) Pemerintah bersih ...(Kompas TV); (14) Kunci pemimpin adalah...(Kompas TV) and (15) Politik hitam putih (Metro TV); (16) Jateng ini bentengnya para santri (Metro TV). Theword bersih at (13) is an metaphorsto good government and has no defects. Kunci (14) is a metaphor for a tool to dosomething. The phrase hitam putih (15) is an metaphorsto the most striking difference. The word benteng (16) is an metaphors to something that can protect.

Hyperbole as in sentence (17) Supaya petani tidak trauma (Kompas TV), (18) Bawang merah yang harganya tinggi (Kompas TV), and (19) Kita perlu membuat satgas untuk nemberantas kemiskinan (Metro TV); (20) Itu itung2annya sangat global dan bukan sesuatu yang turun dari langit (Metro TV). The data (17) of trauma used to warm the psychiatric condition of the farmer as if in a state of great fear (18) harga tingggiis a warming statement to the expensive onion price. Phrase memberantas kemiskinan (19) the form used to warm up the plight of a situation that is worrying and needs to be eradicated. Data (20) the phrase sesuatu yang turun dari langitisused to warm the situation.

\subsection{Discussion}

The genre of discourse used by the candidates most is the type of exposition that includes two types, namely argumentation and hortatory. These two genres have a social function that seeks to provide evidence, so that viewers can accept what the candidates describe (Wiratno, 2014; Kenzhekanova, 2015). The argumentation discourse has a social function to make sure that what the two sides are trying to convince the viewers to be satisfied with the candidate's explanation. Clarity of reason is needed in the campaign discourse will the voters will be steady. However, what has been said was disputed by other couples as a result of that belief can fall back. Therefore, in the debate any weakening of the concept is answered with such reasons already prepared. Each explains their reasons (Lieungnapar et.al., 2017).

Another interesting effort from the candidates is an attempt to retell an interesting past experience. It is also a type of discourse that can be used to generate sympathy for viewers to sympathize and then make choices to the candidate. The attractiveness of the story conveyed in the reconstruction texts became a key factor in the debate. Each candidate, both the candidate for governor and the vice-governor candidate, tells his past in an interesting style (Savtoiu \& Popescu, 2014).

The most widely used language style is repetition. This style is still the most dominant style used in debates to attract attention and reinforce ideas. Iterations in the repetition become the focusing style for the viewer's attention because it is repeated so the viewer becomes more clear about the candidate's statement (Murtafi, 2017; Mahmood et al., 2014). With iteration, the audience becomes more interested in knowing and looking at what the candidate is saying (Tambunan \& Sinambela, 2018; Hariyanto, 2017).

Other figurative languages such as rhetoric, personification, metonymy, metaphor, and hyperbole are the ways in which candidates are able to convey their ideas to draw the attention of their audience or potential voters. The use of figurative language also clarifies what the 
candidates describe. The intentional purpose or intentional delivery of purpose is also intended to be the main attraction (Djajasudarma, 2013; Mahmood et al., 2014; Suhardi, 2015).

In general the debate runs smoothly and in an intimate setting, there is no tension between the two candidates. Even as if both of them are close friends who are chatting casually, although not separated from the seriousness. Debates are delivered in the form of genres with the purpose according to the theme under discussion. Responses and denials were also delivered in an intimate setting. The text genre used is a blend of text, images, and movies or is the text of the audiovisual genre (Wiratno, 2014). Each genre carries a social function according to its genre.

\section{Conclusion}

From the results of the research and discussion above can be concluded things as follows.

(1) The discourse genre in the the debate of Governor candidate in Central Java 2018 in the event of "Rosi and Candidate Leaders of Central Java" in Kompas TV and "Candidate Talk" with the topic "Who deserve Lead Central Java" which was broadcast by Metro $T V$, use macro discourse of conversation genre including discussion. The macro genre consists of micro genres covering the description, exposition (argumentation and hortatory), explanations, recount, and procedures. The social function of each discourse corresponds to its genre.

(2) The language feature used is a repetitive style which is the most widely used type with the purpose of reinforcing and attracting the viewer's attention. Other language feature include rhetoric, personification, metonymy, metaphor, and hyperbole. The feature of language used all have a purpose to attract the attention of the viewers or prospective voters.

\section{Reference}

Bawarshi, A. S. \& Reiff, M. J. 2010. Genre: An introduction to history, theory, research, and pedagogy. USA: Parlor Press.

Creswell, J. W., 2014. Reserch design: qualitative, quantitative, and mixed method approach. USA: SAGE Publications, Inc.

Daniswara, R., Winaya, I.M., \& Parthama, I. G. N. 2016. Meaning of figurative language with reference to four iron maiden songs. Jurnal Humanis, 27, p. 241-247.

Djajasudarma, F. 2013. Semantik 2: Relasi makna paradigmatik, sintagmatik, dan derivasional. Bandung: PT. Refika Aditama.

Fadaee, E. 2011. Symbols, methaphors and similes in literature: a case study of "Anymal Farm". Journal of English Literature, 2(2), p. 19-27.

Hariyanto. 2017. The analysis og figurative language used in the liric of firework by Katy Perry (a study of semantic). English Education: Jurnal Tadris Bahasa Inggris, 10(1), p. 4660.

Ini 171 Daerah yang gelar pilkada serentak. Available at https://news.detik.com/berita. (Accessed Mei 15, 2018).

Kenzhekanova, K. K. 2015. Linguistics feature of political discourse. Mediterranean Journal of Social Science, 6(6), p. 192-199.

Krisnawati, N. L. P. 2017. The translation of English figurative language in Mean Girl movie into Indonesia. Litera Jurnal Bahasa dan Sastra, 3(1), p. 1-8.

Lieungnapar, A., Todd, R.W., \& Trakulkasemsuk, W. 2017. Genre induction from a linguistic approach. Indonesian Journal of Applied Linguistics, 6(2), p. 319-329.

Mahmood, R., Obaid, M., \& Shakir, A. 2014. A critical discourse analysis of figurative language in pakistani english newspaper. International Journal of Linguistics, (6)3, p. 210-216. 
Murtafi, A., Nababan, M. R., \& Djatmika. 2017. The translation analysis of repetition figurative language in novel athousand splended suns, the technique and quality (translation study using stilistics approach). Prasasti: Journal of Linguistics, 2(1), p. 1-20.

Rembuk Nasional, Jokowi ingatkan tahun politik jelang pilpres. Available at https://www.cnnindonesia.com/nasional/.../rembuk-nasional-jokowi-ingatkan-tahunpolitik, (Accessed 15 Mei 2018).

Ren, G. 2010. An overall review of linguistic research on genre. Review of European Studies, (2)2, p. 232-235.

Savtoiu, R. \& Popescu, C. 2014. Humor as a branding strategy in political discourse: A case study from Romania. Revista Signos. Estudios de Linguitica, 47(85), p. 293-320.

Setiyadi, D. B. P. 2012. Kajian wacana tembang macapat: struktur, fungsi, makna, sasmita, sistem kognisi, dan kearifan lokal etnik jawa. Yogyakarta: Media Perkasa.

Sudaryanto. 2016. Metode dan aneka teknik analisis bahasa: pengantar penelitian wahana kebudayaan secara linguistis. Yogyakarta: Sanata Dharma University Press.

Suhardi. 2015. Dasar-dasar Ilmu Semantik. Yogyakarta: Ar-Ruzz Media.

Tambunan, E. R. \& Sinambela, E. 2018. An analysis of figurative meaning on obama's presidential speech. the episteme journal of english literature and linguistics. 4(1), p. 119.

What is political discourse analysis? Available at http://discourses.org/OldArticles/What\%20is\%20Political\%20Discourse\%20Analysis.p df. (Accessed on Mei 15, 2018)

Wiratno, T., Purnanto, D., \& Damaianti, V. 2014. Bahasa Indonesia: ekspresi diri dan akademik. Jakarta: Kementerian Pendidikan dan Kebudayaan.

Wulan, A. P. 2017. Analisis wacana dan edukasi: semiotik multilodal kartun Indonesia "Adit Sopo Jarwo episode bakso hilang" vs kartun Malaysia "Upin-Ipin episode ekosistem". In the 5th Urecol Proceeding. Yogyakarta: Universitas Ahmad Dahlan, p. 1104-1117. 